\title{
MODERN OPPORTUNITIES FOR IMPROVING QUALITY OF BAKERY PRODUCTS VIA REALIZING THE BREAD WHEAT GENETIC POTENTIAL-BY-ENVIRONMENT INTERACTIONS (review)
}

\author{
E.K. KHLESTKINA ${ }^{1,}$, , E.V. ZHURAVLEVA ${ }^{3}$, T.A. PSHENICHNIKOVA1, \\ N.I. USENKO ${ }^{2}$, E.V. MOROZOVA ${ }^{1}$, S.V. OSIPOVA ${ }^{4}$, M.D. PERMYAKOVA ${ }^{4}$, \\ D.A. AFONNIKOV1, 2, Yu.S. OTMAKHOVA 2,5
}

\begin{abstract}
${ }^{1}$ Federal Research Center Institute of Cytology and Genetics SB RAS, Federal Agency of Scientific Organizations, 10, prosp. Akademika Lavrent'eva, Novosibirsk, 630090 Russia, e-mail khlest@bionet.nsc.ru (corresponding author), wheatpsh@bionet.nsc.ru, emorozova@bionet.nsc.ru, ada@bionet.nsc.ru;

${ }^{2}$ Novosibirsk State University, 2, ul. Pirogova, Novosibirsk, 630090 Russia, e-mail n.i.usenko@yandex.ru;

${ }^{3}$ Federal Agency of Scientific Organizations, 14, ul. Solyanka, Moscow, 109028 Russia, e-mail zhuravleva@fano.gov.ru;

${ }^{4}$ Siberian Institute of Plant Physiology and Biochemistry SB RAS, Federal Agency of Scientific Organizations, 132, ul. Lermontova, Irkutsk, 664033 Russia, e-mail svetlanaosipova2@mail.ru, marperm@rambler.ru;

5 Institute of Economics and Industrial Engineering SB RAS, Federal Agency of Scientific Organizations, 17, prosp. Akademika Lavrent'eva, Novosibirsk, 630090 Russia

ORCID: Khlestkina E.K. orcid.org/0000-0002-8470-8254

The authors declare no conflict of interests

Acknowledgements:

Carried out under the ICG SB RAS budget project № 0324-2016-0001. Supported by Russian Foundation for Basic Research (grant № 16-29-12877)

Received April 2, 2017
\end{abstract}

\section{Abstract}

The purpose of this interdisciplinary research is to analyze the available data on the domestic market of bakery products, assess the factors resulting in increase of the bread consumption, and opportunities of improvement of technological properties of flour and dough through the realization of the genetic potential of bread wheat varieties, taking into account environmental factors. In modern conditions, in the bakery products market of such negative tendencies are observed as decrease in volumes of bread production and deterioration of quality of the products. Among the various factors influencing the formation of these trends, one can point out the poor quality of flour, accompanied by deterioration in the rheological properties of the dough. In the practice, the correction of flour of inadequate quality is increasingly being made through the introduction of chemical improvers, which contributes to improving the technological process. At the same time there is a loss of traditional taste and a change in the consumer characteristics of bread, which leads to the refusal or reduction of consumption of bread by a part of the population of our country. This review summarizes data on the dynamics of average per capita consumption of bread and bakery products and the change in the ratio of these indicators to the consumption of meat products. An alternative approach to solving the problems of flour quality can be attributed to the possibilities of natural improvement of its initial characteristics through the realization of the genetic potential of bread wheat varieties, taking into account environmental factors that ultimately influence the formation of technological properties of flour and dough. In recent years, data have been accumulated that have made significant progress in understanding the complex interaction of various genetic systems and biochemical processes underlying the formation of grain properties that affect the quantity and quality of the flour. Integral components in this complex interaction are the environmental factors, under the influence of which the physiological and biochemical processes are modulated, and the mode of realization of genetic information is changing. The article summarizes the data on the influence of various environmental factors on the technological properties of flour and dough and describes the possibilities of modern IT-support of the selection process, facilitating the evaluation of quantitative characteristics and taking into account the relationship between genotype, phenotype and environmental conditions. Advances in the identification of genetic factors affecting the technological properties of flour and dough are discussed and sources of useful variants of these genes are considered. The importance of the use of winter bread wheat for increasing the share of production of high-quality nutritive grains is emphasized, as well as the results of the search for donors of useful genes among the old varieties of spring bread wheat. Among the latter, varieties with a high content of raw gluten and high elasticity of the dough have been identified. In conclusion, the ways of applying data on the influence of genetic and environmental factors on the formation of technological properties of flour and dough in a selection experiment are dis- 
cussed, and the importance of obtaining varieties with genetically determined high strength of flour as a source of natural improver of weak flour is replaced in place of widely used chemical additives.

Keywords: wheat, bread, technological properties, bread-making quality, genes, genetics, physiological processes, biochemical characteristics, ecological factors

Domestication of wheat, made it the main foodstuff for millions of people, is a milestone in civilization development. The high nutritional value of bread is due to important nutrients (polysaccharides, proteins, macro and micro-elements, vitamins B1, B2, B5, B9, PP, and also A and E vitamins in the rye bread) which are well metabolized. However, bread popularity is decreasing now [1]. The purpose of this interdisciplinary research is to analyze domestic market of bread and bakery products, factors which affect this market, and ways to improve the nutritional value of bread products basing on knowledges of genetic potential of wheat varieties, biochemical, physiological and ecological mechanism for its realization, bioinformatics and breeding technologies.

Trend in bread production and consumption. Quality problem. In 1925, average per capita wheat and rye bread consumption in proportion to the beef, pork, lamb and fat, was 1.80, and in whole exceeded 4.86 times meat products consumption. According to Federal State Statistics Service (http://www.gks.ru/), in conversion to wheat flour and meat, in 2009 and 2013, the ratio of bread and meat consumption was 1,36 and 1,13 , respectively, according to the statistics of budgets inspections, 1,78 and 1,57 according to food balances, and 1,01 (in 2013) in selective surveys of the ration. So the tendency of a growing share of meat products and decreasing in bakery products persists, despite the differences depending on the way of calculation, or indicators are approximately equal (with a survey, the annual consumption of meat and meat products was $88.2 \mathrm{~kg}$, of bread and bread products $-89.4 \mathrm{~kg}$ ). The "Bread products" group includes flour, cereals, legumes in addition to bread, so the bread and bread products consumption itself is much lower (Table). In analytic publications aggregated figures are often presented, which misinterpret the real data and leads to non-objective conclusions.

Dynamics of average per capita consumption of basic foodstuffs in Russia (kg per year, Federal State Statistics Service data, http:gks.ru/)

\begin{tabular}{|c|c|c|c|c|c|c|c|}
\hline \multirow{3}{*}{ Name } & \multicolumn{7}{|c|}{ Year } \\
\hline & \multirow{2}{*}{2008} & \multirow{2}{*}{2009} & \multirow{2}{*}{2010} & \multirow{2}{*}{2011} & \multirow{2}{*}{2012} & \multicolumn{2}{|c|}{2013 год } \\
\hline & & & & & & total & to $2008, \%$ \\
\hline $\begin{array}{l}\text { Bread and bakery products } \\
\text { (in conversion to wheat) } \\
\text { including: }\end{array}$ & 59.9 & 57.6 & 57.4 & 55.2 & 53.6 & 51.3 & 85.6 \\
\hline wheat bread & 38.9 & 36.6 & 36.5 & 34.7 & 33.3 & 31.7 & 81.5 \\
\hline Rye bread & 17.9 & 17.8 & 17.4 & 16.8 & 16.5 & 15.8 & 88.8 \\
\hline Bakery products & 3.1 & 3.2 & 3.5 & 3.7 & 3.8 & 3.8 & 122.5 \\
\hline Meat products (in conversion to meat) & 75 & 73 & 79 & 81 & 83 & 85 & 113 \\
\hline Ratio of bread: meat products & 0.79 & 0.78 & 0.73 & 0.68 & 0.65 & 0.60 & 75.9 \\
\hline \multicolumn{8}{|c|}{$\begin{array}{l}\text { N o t e. The indicators for finished products are overstated due to Federal State Statistics Service uses special coef- } \\
\text { ficients for conversion of bread to flour. }\end{array}$} \\
\hline
\end{tabular}

So, from 2008 to 2013 just consumption of bread products had grown while wheat bread had decreased to $81.5 \%$ as compared to 2008 . Share of bread in the structure of consumption is the highest (65\% in 2008 and $62 \%$ in 2013) that determines the general tendency, and the ratio of bread and meat products had decreased from 0.79 to 0.60 that was due to reduction of per capita bread consumption and its share vs. meat products. New trend consumption behavior of Russian population modifies the structure of nutrition [2].

The linearity between the development of competition and improvement of quality production have recently been challenging [3). In Krasnoyarsk this year's expertise of the main range showed that $40 \%$ of samples were rejected 
from degustation among which only for the first sort wheat bread category these were 5 samples out of 10 ones [4]. The change of crumb taste and structure, bread holes and thick crust, high friability and growing moldy lead to refusing or decreasing of bread consumption by a part of the population, causing the decrease of the production from $9,005 \mathrm{mln}$ tons to $6,539 \mathrm{mln}$ tons in 2014 [5, 6]. A decline in the quality is mainly determined by the flour properties and, as a consequence, by deterioration of the rheological dough indictors. The improving agents are increasingly applied that enhance ease of manufacturing but cause loses in the traditional taste and some consumer qualities. An alternative approach is the natural improvement of the flour characteristics using genetic potential of varieties and environmental factors affecting formation of baking flour properties.

Bread wheat breeding for grain and flour quality. According to data of Ministry of Agriculture of the Russian Federation (spring 2015), in Russia, $17 \%, 25 \%$ and $41 \%$ sowings account for winter and spring wheat, the remaining cereals and leguminous, and other crops, respectively. Wheat almost by one third provides the daily human need in the energy and almost a quarter of proteins. From June 2015 to June 2016, Russia supplied $24.5 \mathrm{mln}$ tons of wheat grain on the foreign market, became the leading exporter.

A combination of high yields, grain quality, and resistance to abiotic and biotic factors with a high varietal plasticity and adaptability is under the constant control in the breeding programs to provide the most complete realization of genetic potential. Among current trends the adaptive improving is dominating, that is capability of varieties to maximize productivity in certain environmental conditions. To date, 219 varieties of winter wheat and 175 ones of spring soft wheat have been added to the State Register of Protected Selection Achievements of the Russian Federation [8]. Depending on weather conditions, in some regions, spring wheat and in others regions winter wheat may have an advantage in quality [9]. Winter wheat has a higher biological productivity potential: in Russia its average yield is nearly twice as high as spring wheat has [10]. One of the most urgent tasks is short stature, resistant to lodging winter wheat varieties with high yields. The problem is that almost all short stem varieties have small 1000 grains weight, a poor quality of flour. Moreover, short stems negatively correlate with winter resistance. Largely, the problem was solved by interrupting saturating crossings [11]. As a result, intensive short stem varieties were created which surpass tall-growing standards for yields up by 15 centner per ha and not assented in 1000 grains weight and the flour quality.

Over recent decades, the wheat grain quality is tending to diminish. [2]. Quality formation proceed in the field and is determined both by hereditary characteristics and a complex of soil-climatic and agrotechnical conditions. Wheat strength largely depends on the genotype, so considerable attention is paid to breeding varieties that match good grain quality, high yields and other economically valuable traits. One of the approaches is the creation of varieties which are capable of grain forming in different climatic conditions and suitable for the manufacture of baked goods and grain products.

An example of modern investigations is the WHEALBI programs of the European Union countries (http://www.whealbi.eu/) and BREEDWHEAT in France (http://www.breedwheat.fr/) implemented through public-private partnerships. For example, BREEDWHEAT involves 15 scientific laboratories, 10 private companies, which specialize in plant breeding, seed production and grain production, an innovation cluster and technology transfer company. It is planned to optimize the usage of the genetic and ecophysiological adaptation in wheat based on soil-climatic factors and agrotechnologies, and to implement breeding strategies 
based on DNA markers and genomic technologies. A part of this great project is a large-scale phenotyping of more than 4500 varieties and wheat lines on all economically valuable characteristic in 48,000 trial plots from 15 ecological and geographical areas during 9 years. Such large-scale projects include massive data sets. In addition, evaluation of a large number of parameters in large samples necessitates high-performance phenotyping.

Automated estimates of phenotype and relationships between plant genotype, phenotype and environment. Automatic determination of plant phenotypic characteristics [12] by computer image analysis is helpful in rapid collection of accurate information about valuable traits, such as yield and drought resistance. In wheat breeding, the most important traits associated with productivity are 1000 grain weight and the grain number per ear. Their definition manually is arduous. The proposed software and devices allow estimating grain shape and size [12, 13] accurately, and quantitate them. Mainly, this is the recognition of objects on a digital image (as a rule against a light background). Most frequently the grain shape is described by the length and the width [14]. Some methods allow estimation of tens of characteristics (shapes feature, size, and color of grains), and on this basis classification not only the cultivars, but also by the place where the plants grew [15].

Additionally, grain quality and the absence of disease are. For this, technologies based on spectroscopy at near-IR range $(\lambda=401-1000 \mathrm{~nm})$ and hyperspectral images serve. Such methods allow analyzing of chemical composition, particularly grain protein content, starch [16], fibers [17] and injury by insects [18] and molding [19]. To estimate large grain numbers based on image processing, round-the-clock analyze is developed. Such method is proposed for rice grains [20]. It allows to thrash grains up and to determine their amount, size (length, width), 1000 grain weight; diurnal system capacity is over 1400 plants with an error within 1-3\%.

In phenotyping signs which are linked to drought resistant physiological characteristics (water use efficiency, stomatal conductance, etc.) are essentially added by thermal image data processing [21] with a quantitative estimation of the leaf surface temperature. So, it was shown, that in drought transgenic wheat plants with the alfalfa aldose reductase gene have leaves temperature lower [22]. Infrared spectrum or hyperspectral images from drones or small airplanes [23] are fieldused, which allow to control water content in plants over large areas through monitoring of response to arid environment, watering or agrotechnologies.

Therefore, modern methods of mass plant phenotyping allow to consider interrelations among the genotype, phenotype and environmental conditions for the effective selection of stable wheat genotypes in which the grain and flour quality is least affected by adverse environmental factors [24]. These data are also used for automated control of variety cultivating which allows applying a set of measures to ensure the highest quality of grain on time.

The influence of environmental conditions on the technological properties of flour and dough. Main factors are water availability, temperature regime, the composition of chemical elements in the soil (including applied fertilizers), atmospheric air changes, on which depends expression of genetic determinants responsible for technological properties of flour and dough.

Water availability and temperature regime. After pollination, high temperature stress limits starch availability for the reserve accumulation. This results in small grains with low flour outputs [25]. The temperature stress during grain filling increases the protein content and the flour strength; however, at a temperature of more than $30^{\circ} \mathrm{C}$, the composition of proteins and starch changes which significantly affects physical dough properties. Starch biosynthesis is reduced sig- 
nificantly while the protein influenced is insignificantly [26]. Simultaneously, the functional properties of starch and protein are modified [27]. High temperatures affect the ratio of amylose to amylopectin which leads to a reducing dough elasticity. Also, there is a different allocation of starch grains in the endosperm [28]. High air temperature (even for several days) during grain filling reduces both the ratio of glutenin/gliadin, and the level of high-molecular polymers in gluten, the content of which correlates to the strength of flour. This is due to reduced activity of the enzymes involved in formation of disulfide bonds and activation of heat shock protein biosynthesis which prevailed in the grain and weaken the elasticity of gluten by disruption of its polymerization [29, 30].

Macro- and microelement content in soil. Nitrogen fertilizers are an inalienable element of agro-technologies. They are necessary for the growth of photosynthetically active leaf biomass, from which about $80 \%$ of the nitrogen is remobilized into the maturing grains [31]. Elevation in nitrogen dose increases the protein content in the grain. This increases grain size and flour yield. Growth in protein and gluten contents are linked, which correlates positively with the physical properties of dough. Meanwhile, the biosynthesis of high-polymeric gluten fractions enhances which make dough more elastic [3234]. Late $\mathrm{N}$-fertilization and foliar feeding are especially beneficial. The rheological properties of the dough and the bread appearance are improved, and its volume increases. It is known that the water deficit in the seed-filling period deteriorate all qualitative properties. High nitrogen doses under these conditions improve grain quality [35]. Modern Italian varieties when compared to the traditional ones can use soil nitrogen much more effectively that results in increased yield and high grain and flour quality both at low and high doses of nitrogen [36].

High nitrogen content along with deficit in sulfur-containing fertilizers can lead to available sulphur deficiency for the normal grain development [37]. The action of this macro element is linked with the significant function of disulfide bonds in the formation of polymeric forms of gluten which ensure its rheological properties. Sulfur is a part of sulfur-containing amino acids, which form disulfide bonds. Sulfur deficiency changes the gluten composition, increasing the S-poor proteins share ( $\omega$-gliadins, high-molecular glutenins) through $\mathrm{S}$-rich (low-molecular glutenins) [38]. The sulfur-containing fertilization has positive effects on crop yield and some gluten quality parameters in the Mediterranean [39]. In Pakistan, this agronomic method reduced the N:S ratio and increased the protein content in the grain with a significant positive effect on baking index [40]. In Estonia, application of sulfur-containing fertilizer increased sulfurcontaining amino acid content, crude gluten, improved its quality and all main bread-making properties of winter wheat grain [41].

Foliar feeding with microelements along with mineral fertilizers increased the content of monomeric gliadin and polymeric glutenin. It leads to the formation of more disulfide bonds and higher gluten complex polymerization. Addition of $\mathrm{Mn}$ increased grain protein content, gluten, sedimentation index, and grain hardness, $\mathrm{Zn}$ was beneficial for high molecular weight glutenins. In gluten, the high- and low-molecular-weight fraction significantly increased as influenced by $\mathrm{Zn}$ and $\mathrm{Cu}$ [42]. The described effects are related to the fact that microelements serve as cofactors of many cellular enzymes which provide metabolic ways of the proteins biosynthesis in vital processes, including grain formation.

Atmospheric composition. Effects of global climate changes in the Earth's include an increase of the concentration of carbon dioxide in the atmosphere. In a number of countries, its influence on the formation of technological properties of flour and dough is studied [25, 43-45]. In some studies, besides properties, the changes in the grain proteome under the action of elevated $\mathrm{CO}_{2}$ 
concentration have been assessed [45, 46]. An increasing $\mathrm{CO}_{2}$ in the atmosphere affects the gluten content and leads to a deterioration of baking properties, i.e. the bread volume of and flour strength decreases, while dough kneading takes more time. However, dough extensibility and its stability are not vulnerable to this effect. These data are consistent with the proteomic analysis results, which showed that the main changes affect the expression of genes for high-molecularweight glutenin subunit (HMW-GS). It is well known that, physical and mixing properties of flour and dough depend on the content of high molecular weight glutenin subunits [47-49]. Under elevated $\mathrm{CO}_{2}$ [50], changes had been observed in the ratio of the main protein fractions of gluten, the glutenins and gliadins. By contrast, elevated $\mathrm{CO}_{2}$ concentrations do not reduce the expression of low molecular weight glutenins [45] or reduce their amount not as much as high molecular weight ones [46]. With low-molecular-weight glutenin such rheological properties are connected as dough extensibility and stability [51]. Elevated $\mathrm{CO}_{2}$ decreases the grain protein content, while reducing the $\mathrm{S}, \mathrm{Ca}, \mathrm{Fe}$, and $\mathrm{Zn}$ levels [52].At high induced $\mathrm{CO}_{2}$ concentration, the time and rate of nitrogen remobilization from leaves to wheat grain during wilting vary. Therefore, changing dynamics of nitrogen accumulation in leaves can reduce grain protein level [53].

Effects of environment on protein and carbohydrate complexes of the wheat grain. Changing environmental conditions can affect the formation of viscoelastic properties of the gluten protein complex through labile isomerase and oxidoreductase system. They are able to modify folding the storage proteins, their post-translation modification, the polymerization of glutenin subunits, protein deposition, and probably involved in the grain texture formation. Polymerization of glutenin subunits is the most important stage in the gluten protein network forming. The viscoelastic properties of gluten are molecularly based on the distribution of molecular weights of protein polymers [54].

In 11 studied varieties and 5 hybrids of soft wheat grown in eight different geographical locations, $60-84 \%$ of the stability of baking parameters was due to stabile distribution of molecular weight of glutenin polymers. The environment significantly affected the molecular weight of the polymer fraction [55]. Prolamines can interact with foldases, for example with protein disulfide isomerases (PDI), catalyzing the isomerization of disulfide bonds [26, 56]. Significantly reduced level of insoluble glutenin macro-polymers after the addition of bacitracin, a PDI inhibitor, implies that endogenous proteins of PDI family in the flour suppress the depolymerization of glutenin polymers [57].

If the wheat pant grew at high temperatures $\left(37 / 28{ }^{\circ} \mathrm{C}\right.$, day/night), the heat shock protein expression increased [28]. One of these proteins was localized on the surface of protein bodies [58], accelerating the coagulation and aggregation of prolamins inside them.

Thiol:protein disulfide oxidoreductase (PDO) isolated from maturing wheat grains and classified as glutaredoxin-like protein, catalyzes a disruption of disulfide bonds in gluten proteins and reduces their aggregation capacity [59). Adding this enzyme to flour of different quality wheat varieties has led to a significant increase in extensibility (from 17 to $49 \%$ ). This indicates the essential role of the PDO in the destruction of disulfide bonds in high-polymeric glutenin [60].

Mapping of quantitative trait loci (QTL) for PDO activity and physical dough properties (flour strength and elasticity, water absorbing ability) with use of ITMI mapping population revealed their colocalization [61]. This, probably results from the linkage between the genetic control of PDO activity and the quality of gluten. There is evidence of a close linkage between the content of reduced glutathione, which is maintained by glutathione reductase, and the $\mathrm{SS} / \mathrm{SH}$ status of storage proteins [62]. Reduced glutathione bound to SH-groups 
of glutenin thereby blocks the formation of disulfide bonds, thus preventing polymerization. The increasing in protein-bound glutathione negatively correlates with molecular weights of polymers, and poor quality gluten always has more such proteins [63].

In wheat grains, in addition to the enzymes which catalyze the destruction of S-S bonds, a significant quantities of lipoxygenase (LOX), the key enzyme of lipoxygenase signaling cascade, is present. Its products (fatty acid hydroperoxides) can oxidize SH-groups of storage proteins with the formation of $\mathrm{S}-\mathrm{S}$ bonds, thereby promoting their polymerization. A correlation analysis performed for three sets of substituted and recombinant wheat lines [64] revealed a close linkage between the activity of endogenous LOX in grains and 15 technological parameters, like flour strength, dough elasticity and mixing properties. At the same time, the high activity of LOX negatively correlated with the main quality parameters, while low activity correlated positively, that is, the nature of correlation depended on the enzyme activity. It was concluded that the positive LOX influence on gluten is due to blocking of excess rheologically active thiol groups in storage proteins. It strengthened gluten and reduce the dough extensibility [64]. However, high activity leads to the formation of a large number of S$\mathrm{S}$ bonds and the loss of the optimal dough viscosity, which reduces the quality. The LOX effect on the grain quality seems to be related to its participation in lipid-protein interactions at the interface between the surface of starch granules and protein bodies which largely determine the texture of the grain. Using the recombinant introgression lines of Triticum aestivum/Aegilops tauschii, QTL for LOX activity was detected on chromosome 5D [65], coinciding with the position of the main hardness gene $H a$, which determines the endosperm texture [66, 67]. Successful use of the LOX gene as a target for genomic editing in wheat [68] opens the prospect for the refinement of the effects of mutations in this gene on the properties of grain and flour when using the models obtained. In turn, the LOX expression is changed under the influence of environmental factors $[69,70]$, therefore one of the mechanisms mediating the influence of the environment on the technological properties of flour and dough can be associated with LOX.

Action of environmental factor through the photosynthetic systems is another mechanism. The influence of structural organization of photosynthesis on the gluten quality and quantity was studied in tall and short-stemmed winter wheat varieties [71]. A positive correlation was found between the active photosynthetic potential, proportional to the biomass (through assimilating surface), and the gluten content in the grain. However, a strong negative correlation was found between the energy efficiency coefficient and the gluten quality (by the measurement of gluten deformation). It appears that short-stemmed varieties accumulate more gluten, but of worse quality.

Thus, environmental impact on the technological properties of grain and flour is mediated by various molecular mechanisms and cellular processes which are involved in the formation of protein and carbohydrate complexes during grain maturation. Despite general trends in the response of different genotypes to the same factors, there are genetically determined differences that can result in the maximum realized quality potential of the variety in certain conditions.

Genes and gene donors for improving technological properties of flour and dough. Bakery quality is an integral parameter which depends both on the genotype and the environment conditions. To date, more than 40 genes and QTL affecting technological properties of flour and dough have been mapped, and closely linked DNA markers have been described [2, 9]. More than half of them are responsible for rheological properties (flour strength, 
elasticity, extensibility, water absorption capacity, time of dough formation, stability, and liquefaction). The remaining mapped loci are responsible for milling properties (8 loci), protein and crude gluten content ( 5 loci), starch properties (3 loci), flour color (3 loci) [2, 9]. The integral characteristic of baking properties (volume of baked bread) differently correlates with the mentioned technological indexes. In particular, this parameter is determined by the composition of gluten proteins, which is controlled by the genes for gliadin and glutenin synthesis localized on chromosomes of homeological groups 1 and 6. However, the bread volume is also determined by individual genetic factors, in particular, Lvll gene located in the region of Xgwm480 marker on the long arm of chromosome 3A [72]. Recently, wbm gene with enhanced expression in the developing grain has been detected and sequenced [73]. In the 54 spring varieties from the CIMMYT collection (International Maize and Wheat Improvement Center, Mexico), different alleles of this gene are associated with low or high baking properties [74].

Among donors of the desired gene alleles affecting technological properties, both modern commercial varieties of soft wheat and lines with fragments of genomes introgressed from wheat relatives are distinguished [2, 75]. Special attention should be paid to the comparative evaluation of the technological properties of flour and dough in modern varieties as compared with wheat cultivated till 1960-1970. As a turning point, it was the 1960s as the period of the "green" revolution and rapid post-war development of science and economy, and the reindustrialization of agriculture. Study of 14 Italian soft wheat varieties cultivated from 1916 to 1994, as well as two populations cultivated in the 1900s, showed that the varieties used after 1970 are higher in flour strength and the ratio of dough elasticity to tensile [36]. The authors concluded that modern varieties that are better in nitrogen absorption and have higher productivity and quality under $\mathrm{N}$ deficit are of interest even for organic farming. A low quality of German varieties of the pre-war and early post-war period is also noted [76].

Russian old-fashioned varieties have a lot of potential. Thus, 45 Siberian varieties of different selection periods were analyzed for the following features: 1000 grains weight which affects the flour output; the grain hardness and the flour particle size which determine the flour use; crude gluten content in grain which determines use and nutritive value of flour; flour strength; dough extensibility and resilience which determine baking properties; resilience to extensibility ratio affecting dough resilience [77]. Note, weight of 1000 grains is more variable in modern varieties and as a whole better than in the old ones. Altai 50 (32.6 g), Fora (31.9 g) and Irtyshanka $10(29.4 \mathrm{~g})$ are especially distinguished on this trait. Old-fashioned varieties are more variable in grain vitreousity, however, higher vitreousity have the modern varieties with the highest index for Novosibirskaya 89 (96.4\%), Novosibirsk $67(93.9 \%)$ and Altai $60(92.3 \%)$, and the oldfashioned varieties Cesium 94 (93.8\%) and Krokhinskaya 10 (92.2\%). The average content of raw gluten in grain is remarkably higher in the old varieties for which a great variability on this feature is also characteristic. The varieties with the largest content of raw gluten were identified, i.e. Tarskaya $2(43.8 \%)$ and Alenka (40.9\%). For flour strength, dough extensibility and resilience, the modern varieties exceeded the old ones. DNA markers are found which admittedly are linked to the genetic factors determining high expression of studied traits [77]. The largest number of such markers was revealed in old varieties for milling properties and gluten content in grain. These markers can be used in selection after further verification.

Among the traditional Siberian varieties of soft wheat, putative gene donors have been detected that can be involved in breeding varieties with specified technological properties. After the primary structure sequencing of the identified 
genetic factors, they can undergo target modification by CRISPR/Cas genomic editing technology. This promising method which allows for non-transgenic modified plant varieties is already being used to improve yielding and resistance in wheat [78].

So, the molecular, biochemical and physiological data on mechanisms that mediate influence of the environment and genetic trait control provide a basis for optimization of genotype $\times$ environment interaction, for example in selection of a variety in combination with agrotechnology to maximize its biological potential on yield and quality. Study of the role of genetic factors in expression of flour and dough technological properties will allow to develop diagnostic DNA markers application of which speeds up breeding and increases its accuracy when creating varieties with genetically determined high strength of flour. Instead of chemical additives, such flour can be a natural improver of weak flour for better quality of bread products. Besides, high technological properties will contribute to an increase Russian grain export.

\section{REFERENCES}

1. Usenko N.I., Poznyakovski i V.M., Otmakhova Yu.S. EKO (Vserossiiskii ekonomicheskii zhurnal), 2016, 1: 109-124 (in Russ.).

2. Khlestkina E.K., Pshenichnikova T.A., Usenko N.I., Otmakhova Yu.S. Vavilovskii zhurnal genetiki i selektsii, 2016, 20(4): 511-527 (doi: 10.18699/VJ15.140) (in Russ.).

3. Ro z m a i n s k i i I.I. Terra Economicus, 2011, 9(1): 8-16 (in Russ.).

4. Eksperty Krasnoyarskogo TSSM snyali s reitingovoi otsenki 40 protsentov issledovannykh obraztsov khleba [Experts withdrew from the rating of 40 percent of the samples of bread examined in Krasnoyarsk]. Available http://www.prodnadzor.info/news/chast-hleba-snjali-s-proverki-ekspertysoobshhili-kakoj-hleb-kachestvennyj.html. Accessed October 01, 2016 (in Russ.).

5. Rossiiskii statisticheskii ezhegodnik [Russian Statistical Yearbook]. Moscow, 2014 (in Russ.).

6. Rossiya $v$ tsifrakh [Russia in Figures]. Moscow, 2015 (in Russ.).

7. Prognoz struktury posevnykh ploshchadei (2016) [Forecast of the structure of sown areas for 2016]. Available http://www.mcx.ru/documents/document/v7_show/34609. Accessed October 01, 2016 (in Russ.).

8. Gosudarstvennyi reestr okhranyaemykh selektsionnykh dostizhenii [State Register of Breeding Achievements]. Moscow, 2016 (in Russ.).

9. Krup n ov a O.V. A comparison of grain quality in spring and winter wheats associated with market classes (review). Agricultural Biology, 2013, 1: 15-25 (doi: 10.15389/agrobiology.2013.1.15eng).

10. Tempy rosta. 2014 [Growth rates]. Available http://mcx.ru/news/news/show/31716.355.htm. Accessed March 25, 2017 (in Russ.).

11. Sandukhadze B.I., Kochetygov V.G., Rybakova M.I., Bugrova V.V., Korovushkina M.S., Guseva N.YU., Morozov A.A., Sandukhadze E.K. Zernobobovye i krupyanye kul'tury, 2013, 2(6): 19-23 (in Russ.).

12. Afonnikov D.A., Genaev M.A., Doroshkov A.V., Komyshev E.G., Pshe ni c h nik ova T.A. Genetika, 2016, 52(7): 788-803 (doi: 10.7868/S001667581607002X) (in Russ.).

13. Huang M., Wang Q.G., Zhu Q.B., Q in J.W., Huang G. Review of seed quality and safety tests using optical sensing technologies. Seed Sci. Technol., 2015, 43(3): 337-366 (doi: 10.15258/sst.2015.43.3.16).

14. Tanabata T., Shibaya T., Hori K., Ebana K., Yano M. Smart Grain: highthroughput phenotyping software for measuring seed shape through image analysis. Plant Physiol., 2012, 160(4): 1871-1880 (doi: 10.1104/pp.112.205120).

15. S m y k lova I., Grillo O., Bjelk ova M., P avelek M., Ve nora G. Phenotypic evaluation of flax seeds by image analysis. Ind. Crop. Prod., 2013, 47: 232-238 (doi: 10.1016/j.indcrop.2013.03.001).

16. Yang X., Wang L., Zhou X., Shuang S., Zhu Z., Li N., Li Y., Liu F., Liu S., L u P., Re n G., D o ng C. Determination of protein, fat, starch, and amino acids in foxtail millet Setaria italica (L.) Beauv. by Fourier transform near-infrared reflectance spectroscopy. Food Sci. Biotechnol., 2013, 22: 1495-1500 (doi: 10.1007/s10068-013-0243-1).

17. Armstrong P.R., Tallada J.G., Hurburgh C., Hildebrand D.F., Specht J.E. Development of single-seed near-infrared spectroscopic predictions of corn and soybean constituents using bulk reference values and mean spectra. Transactions of the ASABE, 2011, 54: 1529-1535 (doi: 10.13031/2013.39012).

18. S ingh C.B., J ayas D.S., Paliwal J., White N.D.G. Fungal damage detection in 
wheat using shortwave near-infrared hyperspectral and digital colour imaging. International Journal of Food Properties, 2012, 15: 11-24 (doi: 10.1080/10942911003687223).

19. Shahin M.A., Sy mons S.J., H a t c he r D.W. Quantification of mildew damage in soft red winter wheat based on spectral characteristics of bulk samples: A comparison of visiblenear-infrared imaging and near-infrared spectroscopy. Food Bioprocess Technol., 2014, 7: 224234 (doi: 10.1007/s11947-012-1046-8).

20. Duan L., Yang W., Huang C., Liu Q. A novel machine-vision-based facility for the automatic evaluation of yield-related traits in rice. Plant Methods, 2011, 7(1): 1-13 (doi: 10.1186/1746-4811-7-44).

21. Munns R., James R.A., S i rault X.R., Furbank R.T., J on es H.G. New phenotyping methods for screening wheat and barley for beneficial responses to water deficit. J. Exp. Bot., 2010, 61(13): 3499-3507 (doi: 10.1093/jxb/erq199).

22. Fehér-Juhász E., Majer P., S a s s L., Lantos C., C s iszár J., Tu róczy Z., Mihály R., Mai A., Horváth G.V., Vass I., Dudits D., Pauk J. Phenotyping shows improved physiological traits and seed yield of transgenic wheat plants expressing the alfalfa aldose reductase under permanent drought stress. Acta Physiologiae Plantarum, 2014, 36(3): 663-673 (doi: 10.1007/s11738-013-1445-0).

23. Gonzalez-Dugo V., Hernande Z P., Solis I., Z a r co-Tejada P.J. Using highresolution hyperspectral and thermal airborne imagery to assess physiological condition in the context of wheat phenotyping. Remote Sens., 2015, 7(10): 13586-13605 (doi: 10.3390/rs71013586).

24. Lopes M.S., Rebetzke G.J., Rey nolds M. Integration of phenotyping and genetic platforms for a better understanding of wheat performance under drought. J. Exp. Bot., 2014, 65(21): 6167-6177 (doi: 10.1093/jxb/eru384).

25. Nuttall J.G., O' Le ary G.J., Panozzo J.F., Walker C.K., B a rlow K.M., Fitzge ra ld G.J. Models of grain quality in wheat - a review. Field Crop Res., 2017, 202: 136-145 (doi: 10.1016/j.fcr.2015.12.011).

26. Du Pont F.M., H u rkman W.J., Tanaka C.K., Chan R. BiP, HSP70, NDK and PDI in wheat endosperm. I. Accumulation of mRNA and protein during grain development. Physiologia Plantarum, 1998, 103: 70-79.

27. Faroo q M., B ra m ley H., Palt a J.A., S id d i qu e K.H.M. Heat stress in wheat during reproductive and grain-filling phases. Crit. Rev. Plant Sci., 2011, 30: 1-17 (doi: 10.1080/07352689.2011.615687).

28. Hurkman W.J., Vense 1 W.H., Tanaka C.K., Whitehand L., Altenbach S.B. Effect of high temperature on albumin and globulin accumulation in the endosperm proteome of the developing wheat grain. J. Cereal Sci., 2009, 49: 12-23 (doi: 10.1016/j.jcs.2008.06.014).

29. Blumenthal C.S., B arlow E.W.R., Wrigley C.W. Growth environment and wheat quality: the effect of heat stress on dough properties and gluten proteins. J. Cereal Sci., 1993, 18: 3-21.

30. Blumenthal C.S., Stone P.J., Gras P.W., Bekes F., Clarke B., Barlow E.W.R., A p p els R., W rigle y C.W. Heat-shock protein 70 and dough-quality changes resulting from heat stress during grain filling in wheat. Cereal Chem., 1998, 75: 43-50.

31. Hawkesford M.J. Reducing the reliance on nitrogen fertilizer for wheat production. $J$. Cereal Sci., 2014, 59: 276-283 (doi: 10.1016/j.jcs.2013.12.001).

32. Pelto ne $\mathrm{n}$ J., Virto ne $\mathrm{n}$ A. Effect of nitrogen fertilizers differing in release characteristics on the quantity of storage proteins in wheat. Cereal Chem., 1994, 71: 1-5.

33. Thomason W.E., Phillips S.B., Pridgen T.H., Kenner J.C., Griffey C.A., $\mathrm{B}$ e a h m B.R., S e a b o u r n B.W. Managing nitrogen and sulfur fertilization for improved bread wheat quality in humid environments. Cereal Chem., 2007, 84: 450-462 (doi: 10.1094/CCHEM84-5-0450).

34. Xue Ch., Schulte auf'm Erley G., Rossmann A., Schuster R., Koehle r P., M ühli ng K.-H. Split nitrogen application improves wheat baking quality by influencing protein composition rather than concentration. Front. Plant Sci., 2016, 7: 738 (doi: 10.3389/fpls.2016.00738).

35. Massoudifar O., Kodjouri F.D., Moham madi G.N., Mirhadi M.J. Effect of nitrogen fertilizer levels and irrigation on quality characteristics in bread wheat (Triticum aestivum L.). Archives of Agronomy and Soil Science, 2014, 60: 925-934 (doi: 10.1080/03650340.2013.856004).

36. Guarda G., P a d ova n S., D e log u G. Grain yield, nitrogen-use efficiency and baking quality of old and modern Italian bread-wheat cultivars grown at different nitrogen levels. Eur. J. Agron., 2004, 21: 181-192 (doi: 10.1016/j.eja.2003.08.001).

37. Ske r rit J.H., Lew P.H., C a s t 1 e S.L. Accumulation of gliadin and glutenin polypeptides during development of normal and Sulphur-deficient wheat seed: Analysis using specific monoclonal antibodies. J. Exp. Bot., 1988, 39(203): 723-737.

38. Shew ry P.R., T at ham A.S. Disulfide bonds in wheat gluten protein. J. Cereal Sci., 1997, 25: $135-146$.

39. E re k u l O., G ötz K.-P., K o c a Y.O. Effect of sulphur and nitrogen fertilization on breadmaking quality of wheat (Triticum aestivum L.) varieties under Mediterranean climate conditions. J. Appl. Bot. Food Qual., 2012, 85: 17-22. 
40. Shahsavani S., Gholami A. Effect of sulfur fertilization on breadmaking quality of three winter wheat varieties. Pakistan Journal of Biological Sciences, 2008, 11: 2134-2138.

41. Järvan M., Edesi L., Adamson A., Lukme L., Akk A. The effect of sulphur fertilization on yield, quality of protein and baking properties of winter wheat. Agronomy Research, 2008, 6(2): 459-469.

42. Stepien A., Wojtk owiak K. Effect of foliar application of $\mathrm{Cu}, \mathrm{Zn}$, and $\mathrm{Mn}$ on yield and quality indicators of winter wheat grain. Chilean J. Agric. Res., 2016, 76(2): 220-227 (doi: 10.4067/S0718-58392016000200012).

43. Ki mball B.A., Morris C.F., Pinter P.J., Wall G.W., Hunsaker D.J., Ad a msen F.J., La Morte R.L., Le avit t S.W., Thompson T.L., Matthias A.D., B rooks T.J. Elevated $\mathrm{CO}_{2}$, drought and soil nitrogen effects on wheat grain quality. New Phytologist, 2001, 150: 295-303.

44. Högy P., Wi eser H., Köhler P., Schwadorf K., Breuer J., Franzaring J., $\mathrm{Munt}$ ifering R., Fang meie $\mathrm{r}$ A. Effects of elevated $\mathrm{CO}_{2}$ on grain yield and quality of wheat: results from a three-year FACE experiment. Plant Biol., 2009, 11(Suppl. 1): 60-69 (doi: 10.1111/j.1438-8677.2009.00230.x).

45. Fernando N., Panozzo J., Tausz M., Norton R., Fitzgerald G., Khan A., $\mathrm{S}$ e n e w e e r a S. Rising $\mathrm{CO}_{2}$ concentration altered wheat grain proteome and flour rheological characteristics. Food Chem., 2015, 170: 448-454.

46. Högy P., Zörb C., Langenkämper G., B et s che T., Fangmei e r A. Atmospheric $\mathrm{CO}_{2}$ enrichment changes the wheat grain proteome. J. Cereal Sci., 2009, 50(2): 248-254 (doi: 10.1016/j.jcs.2009.06.002).

47. M a c Rit c h i e F. Evaluation of contributions from wheat protein fractions to dough mixing and bread making. J. Cereal Sci., 1987, 6: 259-268 (doi: 10.1016/S0733-5210(87)80063-2).

48. Mac Ritchie F., Kas a rda D.D., Kuz micky D.D. Characterization of wheat protein fractions differing in contributions to bread-making quality. Cereal Chem., 1991, 68: 122-130.

49. Uthayakumaran S., Newberry M., Keentok M., S toddard F.L., Bekes F. Basic rheology of bread dough with modified protein content and glutenin-to-gliadin ratio. $\mathrm{Ce}$ real Chem., 2000, 77: 744-749 (doi: 10.1094/CCHEM.2000.77.6.744-749).

50. Wi ese r H., M a nde rs cheid R., Erbs M., Weige l H.J. Effects of elevated atmospheric $\mathrm{CO}_{2}$ concentrations on the quantitative protein composition of wheat grains. J. Agr. Food Chem., 2008, 56(15): 6531-6535.

51. Panozzo J.F., Eagles H.A., Wo ot to $n$ M. Changes in protein composition during grain development in wheat. Aust. J. Agr. Res., 2001, 52(4): 485-493.

52. Fernando N., Panozzo J., Tausz M., Norton R., Fitzgerald G., Senewe e $\mathrm{r}$ a S. Rising atmospheric $\mathrm{CO}_{2}$ concentration affects mineral nutrient and protein concentration of wheat grain. Food Chem., 2012, 133(4): 1307-1311 (doi: 10.1016/j.foodchem.2012.01.105).

53. Taub D.R., Mille r B., Allen H. Effects of elevated $\mathrm{CO}_{2}$ on the protein concentration of food crops: a meta-analysis. Glob. Change Biol., 2008, 14: 565-575.

54. Shewry P.R., Underwood C., Wan Y., Lovegrove A., Bhandan D., Toole G., Mills C.E.N., Dehyer K., Mitchell R.A.C. Storage product synthesis and accumulation in developing grains of wheat. J. Cereal Sci., 2009, 50: 106-112 (doi: 10.1016/j.jcs.2009.03.009).

55. Le melin E., Branlard G., S a lvo L., Le in V., A u s s e nac T., Dayd e J. Breadmaking stability of wheat flour: Relation between mixing properties and molecular weight distribution of polymeric glutenins. J. Cereal Sci., 2005, 42(3): 317-326.

56. Take moto Y., Coughlan S.J., Okit a T.W., S a to h H., Og aw a M., Ku ma ma $\mathrm{ru}$ T. The rice mutant esp2 greatly accumulates the glutelin precursor and deletes the protein disulfide isomerase. Plant Physiol., 2002, 128(4): 1212-1222 (doi: 10.1104/pp.010624).

57. Koh A., Nishimura K., Urade R. Relationship between endogenous protein disulfide isomerase family proteins and glutenin macropolymer. J. Agric. Food Chem., 2010, 58(24): 12970-12975 (doi: 10.1021/jf103347p).

58. Li X., Wu Y., Zhang D.Z., Gillikin J.W., Boston R.S., Franceschi V.R., Okita T.W. Rice prolamin protein body biogenesis: a BiP-mediated process. Science, 1993, 262: 1054-1056.

59. O si pova S.V., Permyakov A.V., M it rofanova T.N., Dudareva L.V., Truf a n o v V.A. Biokhimiya, 2005, 70(8): 1130-1136 (in Russ.).

60. Osipova S.V., Permyakov A.V., Mitrofanova T.N., Trufanov V.A., Ermakova M.F., Chist y a k ova A.K., Pshenichnikova T.A. GSH-dependent protein disulfide oxidoreductase of wheat grain: activity in maturing wheat kernels and relationship with rheological properties of dough. Cereal Res. Commun., 2007, 35(3): 1477-1486 (doi: 10.1556/CRC.35.2007.3.12).

61. Pshenichnikova T.A., Osipova S.V., Permyakova M.D., Mitrofanova T.N., Lokhvasse r U., Reder M., B e rne r A. Genetika, 2008, 44(5): 654-662 (in Russ.).

62. Rhazi L., Cazalis R., Le melin E., A us s e n a c Y. Changes in the glutathione thioldisulfide status during wheat grain development. Plant Physiol. Bioch., 2003, 41: 895-902 (doi: 10.1016/S0981-9428(03)00134-7).

63. Li W., Tsiami A.A., B olle cker S.S., S chofield J.D. Glutathione and related thiol 
compounds. II. The importance of protein bound glutathione and related protein-bound compounds in gluten proteins. J. Cereal Sci., 2004, 39: 213-224 (doi: 10.1016/j.jcs.2003.08.003).

64. Permyakova M.D., Trufanov V.A., Pshenichnikova T.A., Ermakov a M.F. Prikladnaya biokhimiya i mikrobiologiya, 2010, 46(1): 96-102 (in Russ.).

65. Permyakova M.D., Permyakov A.V., Osipova S.V., Pshenichnikova T.A., Shishparenok A.A., Rudikovskaya E.G., Rudikovskii A.V, Verkhotu rov V.V., Berner A. Fiziologiya rastenii, 2017, 64(1): 1-14 (doi: 10.7868/S0015330317010110) (in Russ.).

66. Law C.N., Young C.F., B rown J.W.S., S n a p e J.W., Worland A.J. The study of grain protein control in wheat using whole chromosome substitution lines. In: Seed protein improvement by nuclear techniques. International Atomic Energy Agency, Vienna, Austria, 1978: 483-502.

67. M o r r is C.F., D e M a c o n V.L., G i roux M.J. Wheat grain hardness among chromosome $5 \mathrm{D}$ homozygous recombinant substitution lines using different methods of measurement. Cereal Chem., 1999, 76(2): 249-254 (doi: 10.1094/CCHEM.1999.76.2.249).

68. Zhang Y., Liang Z., Zong Y., Wang Y., Liu J., Chen K., Qiu J.-L., Gao C. Efficient and transgene-free genome editing in wheat through transient expression of CRISPR/Cas9 DNA or RNA. Nature Communications, 2016, 7: 1261 (doi: 10.1038/ncomms12617).

69. Veronico P., Giannino D., Melillo M.T., Leone A., Reyes A., Kenne d y M.W., B l e ve - $\mathrm{Z}$ a c h e o T. A novel lipoxygenase in pea roots. Its function in wounding and biotic stress. Plant Physiol., 2006, 141(3): 1045-1055 (doi: 10.1104/pp.106.081679).

70. Permyakova M.D., Permyakov A.V., Osipova S.V., Pshenichnikova T.A. Prikladnaya biokhimiya i mikrobiologiya, 2012, 48: 1-6 (in Russ.).

71. Pet rova L.N., E ros he n k o F.V. Nauchnyi zhurnal KubGAU, 2006, 24(8): 1-10 (in Russ.).

72. Law C.N., B hand ari D.G., S $1 \mathrm{mon}$ S.E., Greenwe 11 P.W., Foot I.M., Cau va in S.P., S a ye rs E.J., Worland A.J. Novel genes on chromosome 3A influencing bread making quality in wheat, including a new gene for loaf volume, Lvl 1. J. Cereal Sci., 2005, 41: 317-326 (doi: 10.1016/j.jcs.2004.11.003).

73. Furtado A., Bundock P.C., Banks P.M., Fox G., Yin X., Hen ry R.J. A novel highly differentially expressed gene in wheat endosperm associated with bread quality. Scientific Reports, 2015, 5: 10446 (doi: 10.1038/srep10446).

74. Guzmán C., Xia o Y., C ross a J., González-Santoyo H., Huerta J., S ingh R., Dreisigacker S. Sources of the highly expressed wheat bread making $(w b m)$ gene in CIMMYT spring wheat germplasm and its effect on processing and bread-making quality. Euphytica, 2016, 209: 689-692 (doi: 10.1007/s10681-016-1659-5).

75. Mitrofanova O.P., Khakimova A.G. Vavilovskii zhurnal genetiki $i$ selektsii, 2016, 20(4): 545-554 (doi: 10.18699/VJ16.177) (in Russ.).

76. Hagel I. Sulfur and baking-quality of bread making wheat. Landbauforschung Völkenrode, 2005, Special Issue 283: 23-36.

77. Morozova E.V., Pshenichnikova T.A., Simonov A.V., Shchukina L.V., Chis tyakova A.K., Khlestkina E.K. A comparative study of grain and flour quality parameters among Russian bread wheat cultivars developed in different historical periods and their association with certain molecular markers. Proc. 16 ${ }^{\text {th }}$ Int. EWAC Conf. (24-29 May, 2015, Lublin, Poland). European Cereal Genetics Co-operative (EWAC) Newsletter (Gatersleben), 2016, 16: 49-56.

78. Korotkova A.M., Gerasimova S.V., Shumnyi V.K., Khlestkina E.K. Vavilovskii zhurnal genetiki i selektsii, 2017, 21(2): 250-258 (doi: 10.18699/VJ17.244) (in Russ.). 